\title{
Economic Sanctions, Procedural Rights and Judicial Scrutiny: Post-Kadi Developments
}

\author{
TAKIS TRIDIMAS
}

\begin{abstract}
The judgment of the Court of Justice of the European Union in Kadi ${ }^{1}$ is of defining constitutional importance. The Court understood the EU Treaties (at the time, the EC Treaty) as establishing their own constitutional space, asserted the autonomy of EU law vis-à-vis international law and held that responses to emergencies should be handled through, rather than outside, the bounds of the EU Treaties. The judgment is predicated on liberal democratic ideals and views respect for legality as a sine qua non in times of emergency. This chapter seeks to discuss selected case law developments after Kadi. It focuses on the effect of invalidity of sanctions on third parties, issues pertaining to the validity and interpretation of Council Regulation 881/2002/EC, ${ }^{2}$ economic sanctions against nuclear proliferation and corresponding developments in the case law of the UK Supreme Court. It does not deal exhaustively with post-Kadi case law. ${ }^{3}$ Section I provides a brief introduction to the judgment in Kadi. Section II explores the effect of the ruling on third parties. Section III discusses a selection of recent case law of the Court of Justice and the General Court, and section IV explores in some detail the judgment of the UK Supreme Court in Jabar Abmed. ${ }^{4}$
\end{abstract}

\footnotetext{
1 Joined Cases C-402/05 P \& C-415/05 P Kadi and Al Barakaat International Foundationv Council and Commission [2008] ECR I-6351 ('Kadi').

2 Council Regulation 881/2002/EC of 27 May 2002 imposing certain specific restrictive measures directed against certain persons and entities associated with Usama bin Laden, the Al-Qaeda network and the Taliban, [2002] OJ L139/9.

3 The chapter does not deal exhaustively with the case law of the General Court generated by sanctions lists introduced by the European Community and not by the Sanctions Committee of the UN. For these cases, see, among others, Case T-284/08 People's Mojahedin Organization of Iran $v$ Council (OMPI III) [2008] ECR II-3487; Case T-256/07 People's Mojahedin Organisation of Iran v Council (OMPI II) [2008] ECR II-3019; Case T-228/02 Organisation des Modjahedines du peuple d'Iran v Council (OMPI I) [2006] ECR II-4665.

4 [2010] UKSC 2;[2010] 2 WLR 378.
} 


\section{THE JUDGMENT IN KADI}

$\mathrm{I}$

N KADI, THE Court of Justice was concerned with the validity of Regulation 881/2002/EC, by which the Council implemented United Nations Security Council (UNSC) Resolution 1390 (2000) imposing economic sanctions on non-State actors associated with Osama Bin Laden and the Al-Qaeda network. The names of the persons included in the sanctions list were determined by the UN Sanctions Committee which had been set up under UNSC Resolution 1267 (1999). The basic findings of the Court may be summarised as follows. First, the Court held that the European Community (now Union) has competence to adopt economic sanctions against individuals on the basis of Articles 301, 60(1) and 308 of the EC Treaty ${ }^{5}$ (Articles 215, 75, 352 TFEU). Secondly, it held that measures adopted by the Community/Union institutions to give effect to UNSC resolutions are subject to review on grounds of respect for fundamental rights as protected by EU law. The Court adopted a dualist approach, holding that, whilst it does not have power to review the lawfulness of a UNSC resolution, it does have jurisdiction to review the compatibility of measures adopted by the Community institutions with the Treaty. Such review of an EU regulation implementing a UNSC resolution does not entail any challenge to the primacy of that resolution in international law. ${ }^{6}$ The Court upheld the paramountcy of fundamental rights, recalling its judgment in Les Verts and reiterating that neither the Member States nor the EU institutions can avoid review of the conformity of their acts with the EC Treaty. ${ }^{7}$ Thus, in the Court's rationale, the primacy of the UN Charter takes place only in the sphere of international law. It does not penetrate the constitutional space of the EU and, within that space, it cannot take precedence over the general principles of law of which fundamental rights form a part. ${ }^{8}$ On that basis, the Court proceeded to annul Regulation $881 / 2002 / \mathrm{EC}$, by which the assets of the applicants had been frozen, on the ground that the applicants' right to a hearing, the right to judicial protection and the right to property had been infringed. The applicants had not been informed of the evidence against them, no reasons had been given for the inclusion of their names in the sanctions list and they had not been afforded any opportunity to put their case. ${ }^{9}$

\footnotetext{
5 Arts 60(1) and 301 have now been replaced by Arts 75 and 215 TFEU respectively, which provide expressly for the imposition of sanctions against non-State actors. Art 308 has been replaced by Art 352 TFEU.

6 Kadi, above n 1, paras 287-88.

7 Case 294/83 Les Verts $v$ Parliament [1986] ECR 1339, para 23; Kadi, above n 1, para 281.

8 Kadi, above n 1, para 308.

9 Ibid, paras $345 \mathrm{ff}$.
} 
The judgment in Kadi has been the subject of extensive commentary. ${ }^{10} \mathrm{It}$ suffices here to make some brief points.

It may be said that the judgment carries a 'disobedience value'. If the Court of Justice trumps the UNSC, what is there to prevent the courts of another country, perhaps one which shows much less respect for the values of human rights, from trumping UNSC resolutions for being incompatible with its own constitutional principles? Seen in that context, the judgment appears to contribute to the fragmentation of international law and undermine the authority of the Security Council.

It is correct that, if the Security Council is to fulfil its role as the ultimate guarantor of world peace and security, UNSC resolutions must be complied with and enforced effectively at national level. Full and effective enforcement requires the support not only of the executive but of all branches of government. The judiciary should play its role by according due weight to decisions emanating from the Security Council. Respect for the Security Council, however, does not equate to government without law. Under Article 103 of the UN Charter, the primacy of the Charter and obligations arising under it apply in the sphere of international law. They do not interfere with the domestic law of the UN Member States, neither do they require those States to abrogate their own constitutional requirements. The classic argument of limited constitutional delegation applies here in full as it applies in the context of the EU: a national government cannot transfer to the UN more powers than it itself possesses under its national constitution. The ruling of the Court of Justice of the European Union can therefore be viewed as a procedural one: Member States may not use the European Community (now Union) to pursue political ends unless they observe the limitations imposed by the rule of law as they are articulated by the substantive rules and institutional arrangements established by the Treaty. The risk of disobedience identified above is inherent in Article 103 of the UN Charter, which operates only in the sphere of international law and does not interfere with the internal legal systems of UN Member States. There is no evidence to suggest that the courts of

10 The judgment has generated a huge bibliography. See, among others, G de Búrca, 'The EU, the European Court of Justice and the International Legal Order after Kadi' (2009) 51 Harvard International Law Journal, available at SSRN: <http://ssrn.com/abstract=1321313>, accessed 30 July 2010; D Halberstam and E Stein, 'The United Nations, the European Union, and the King of Sweden: Economic Sanctions and Individual Rights in a Plural World Order' (2009) 46 CML Rev 13, available at SSRN: <http://ssrn.com/abstract=1312082>, accessed 30 July 2010; see the contributions in the symposium on the Kadi judgment (2009) 28 YEL 531-700; JE Khushal Murkens, 'Countering Anti-Constitutional Argument: The Reasons for the European Court of Justice's Decision in Kadi and Al Barakaat' (2008-2009) 11 CYELS 15; T Tridimas and JA Gutierrez-Fons, 'EU Law, International Law and Economic Sanctions against Terrorism: The Judiciary in Distress?' (2009) 32 Fordham Journal of International Law 660; T Tridimas, 'Terrorism and the ECJ: Empowerment and Democracy in the EC Legal Order' (2009) 34 EL Rev 103-26. 
third countries will disrespect the UNSC because of the Court of Justice's judgment. The risk of fragmentation is also inevitable given the growing presence and significance of international law. ${ }^{11}$ It is the quid pro quo for the transfer of more powers to international organisations. By demanding higher standards of human rights, the Court of Justice in fact contributes to the democratisation and legitimacy of international law. The judgment marks the initiation of a constitutional conversation with the UN. In this respect, the Court of Justice should respond positively to the establishment of higher standards of justice by UN agencies. The higher the protection of human rights offered by them, the greater the deference which the Court of Justice should accord them.

It has been argued that, by asserting the primacy of EU human rights over the edicts of the UN, the Court of Justice is behaving towards the Security Council in the way that the German and Italian Constitutional Courts behaved towards it in the aftermath of Internationale Handelsgesellschaft. ${ }^{12}$ There is some truth in this observation. It is correct to say that judicial bodies feel very protective of their own jurisdiction. Just as national constitutional courts consider themselves the guardians of their constitutions, so the Court of Justice sees its task as safeguarding what it perceives to be the integrity and the values of the EU legal order. There does not appear to be, however, any inconsistency on the part of the Court of Justice. In its case law, it offered a set of endogenous standards for the protection of fundamental rights as a quid pro quo for asserting the primacy of EU law. No such set of standards appears to exist as yet at UN level.

Kadi must be viewed, first and foremost, as a statement of principle. It marks the beginning and not the end of the enquiry. The Court of Justice annulled the contested Regulation on grounds of procedure and not on grounds of substance. It preserved the effects of the Regulation for a limited time, thus giving the opportunity to the Council to comply with process rights. Lastly, the judgment tells us little about the way the Court of Justice would balance the need for public security and the prevention of terrorism, on the one hand, and the protection of the rights of the individual, on the other hand. In the circumstances of the case, there was no statement of reasons and a complete absence of the rights of defence. Kadi confirms that

11 See, in this context, the work of the International Law Commission on 'Fragmentation of international law: difficulties arising from the diversification and expansion of international law', available at <http://untreaty.un.org/ilc/summaries/1_9.htm>, accessed 30 July 2010. Contributions on the subject are numerous. For a concise account, see the conclusions of the ILC's study group submitted to the UN General Assembly, available at <http://untreaty. un.org/ilc/texts/instruments/english/draft\%20articles/1_9_2006.pdf>, accessed 30 July 2010, and G Hafner, 'Pros and Cons Ensuing from the Fragmentation of International Law' (2004) 25 Michigan Journal of International Law 849.

12 Case 11/70 Internationale Handelsgesellschaft $v$ Einfuhr- und Vorratsstelle Getreide [1970] ECR 1125. 
the executive enjoys no immunity, but it does not tell us by what standards it will be held accountable. ${ }^{13}$

\section{EFFECT OF THE KADI RULING ON THIRD PARTIES}

\section{A. The position of other persons included in the sanctions list}

In Kadi, the Court of Justice annulled Regulation 881/2002/EC only insofar as it concerned the applicants. ${ }^{14}$ What is the effect of the ruling on other persons listed in Regulation $881 / 2002 / E C$ ? It seems clear that such persons would not be able to challenge the Regulation directly since, by the time the ruling was delivered, they had missed the two-month time limit provided in Article 263(6) TFEU (ex Article 230(5) EC). Under Article 266 TFEU (ex Article $233 \mathrm{EC}$ ), following the ruling in Kadi, the Council is under an obligation to take the necessary measures to comply with the judgment. ${ }^{15}$ According to AssiDöman, however, this does not require the Council to reexamine identical or similar decisions allegedly affected by the same irregularity addressed to other persons. ${ }^{16}$ Although Regulation $881 / 2002 / \mathrm{EC}$ is a measure of general application, the entries of persons in the sanctions list are in effect individual acts to which the rationale of AssiDöman appears to apply by analogy.

Another possibility for a listed person might be to seek to challenge Regulation 881/2002/EC indirectly via the preliminary reference procedure. This, however, appears to be precluded by the TWD principle. ${ }^{17}$ This posits that a person who clearly has direct and individual concern to challenge an

13 For a more detailed discussion of process rights, see the judgments of the General Court in the OMPI cases referred to above $\mathrm{n} 3$.

14 One may presume that the other persons included in the list were in the same position as $\mathrm{Mr}$ Kadi and $\mathrm{Al}$ Barakaat, namely that their fundamental rights had also been infringed. It is clear, however, that the Court could not have extended the scope of its ruling beyond the applicants. Mr Kadi and Al Barakaat had locus standi to challenge the regulation only insofar as it related to them. Any attempt to launch a more general attack would have stumbled upon the lack of direct and individual concern. Furthermore, the Court could adjudicate only within the limits of the action brought by the parties and did not have jurisdiction to rule ultra petita: see Case C-310/97 Commission v AssiDöman Kraft Products AB and others (Woodpulp III) [1999] ECR I-5363. Neither would it be possible for the Court to rule on whether the process rights of other listed persons had been breached without hearing any evidence in relation to them.

15 As stated above, the Court of Justice decided to maintain the effects of the Regulation temporarily in force and gave the Council three months to comply with the process rights of the applicants. See Kadi, above n 1, paras 373-76. Following the judgment, the Commission, by Regulation 1190/2008/EC, [2008] OJ L322/25, re-included Mr Kadi in the sanctions list. This Regulation has been challenged before the CFI (now the General Court), inter alia, on the ground that it suffers from the same procedural irregularities as Regulation 881/2002/EC: see Case T-85/09 Kadiv Commission, introduced on 26 February 2009.

16 AssiDöman, above n 14, para 56.

17 Case C-188/92 TWD v Germany [1994] ECR I-833. 
EU measure directly, and who has failed to do so within the requisite time limit, may not mount a collateral challenge via the preliminary reference procedure. Although the TWD judgment has so far been applied only to decisions ${ }^{18}$ and anti-dumping regulations, ${ }^{19}$ and not to other regulations or directives, ${ }^{20}$ it is arguable that it applies to Regulation 881/2002/EC since, in the circumstances, it was beyond doubt that the applicants had locus standi. The application of TWD to economic sanctions measures is confirmed by the judgment in $E \& F$, which is examined in detail below. ${ }^{21}$ Suffice it to state here that, based on the existing authorities, the avenue of indirect challenge before a national court does not seem open to other listed persons whose standing to challenge directly their inclusion in the list is not in doubt. ${ }^{22}$

It could be argued that an entity whose assets were frozen by Regulation $881 / 2002 / \mathrm{EC}$ could invite the Council to review its position in the light of the judgment in Kadi. If the Council refused, it could then challenge the Council's refusal under Article 263 TFEU (Article 230 EC) or, if the Council remained silent, bring an action for failure to act under Article 265 TFEU (Article 232 EC). This route, however, would be unlikely to bear fruit. The Council's refusal to re-examine the case would not be a new act but simply an act confirming the legal position of the listed person under the Regulation, and would thus not be open to challenge. An action for failure to act would also fail, since the Council could define its position under Article 265 TFEU (Article 232 EC) by adopting a confirmatory decision, which would not be open to review.

If the above analysis is correct, it would mean that the judgment in Kadi has little effect on other persons listed by Regulation 881/2002/EC. The only possibility for such a person might be to bring an action in damages against the Council, but this would be subject to proving the existence of a serious breach; and in any event, it could not lead to release

18 See, eg Case C-178/95 Wiljo NV v Belgian State [1997] ECR I-585.

19 Case C-239/99 Nachi Europe GmbH v Hauptzollamt Krefeld [2001] ECR I-01197.

20 See Case C-241/95 The Queen v Intervention Board for Agricultural Produce ex parte Accrington Beef and Others [1996] ECR I-6699; Case C-408/95 Eurotunnel SA v SeaFrance [1997] ECR I-6315.

21 See section II.B. below.

22 By contrast, it appears that a third party which is adversely affected by the Regulation may challenge its validity via the preliminary reference procedure insofar as it has an interest in the outcome of the proceedings. This derives from the nature of Regulation 881/2002/EC as a measure of general application. In Kadi, above n 1, paras 241ff, the Court of Justice confirmed that although listed persons have direct and individual concern, since they are expressly named in the Annex to the Regulation, that does not detract from its character as a true regulation: it prohibits anyone from making available funds or economic resources to the listed persons, and is thus addressed in a general and abstract manner to all persons who might hold the funds in question. See also Case T-306/01 Yusuf and Al Barakaat International Foundation v Council and Commission [2005] ECR II-3533, paras 186-88. 
of the frozen funds, neither could it serve as the basis for a restitutionary claim. $^{23}$

At first sight, it seems harsh that a listed person cannot require the Council to review his position in the light of the Kadi judgment. The justification for this strict approach is to be found in the principle of legal certainty. As the Court held in TWD and AssiDöman, a measure which has not been challenged by the addressee within the time limit laid down in Article 263 TFEU (ex Article 230 EC) becomes definitive as against him. ${ }^{24}$ The requirements of the rule of law are satisfied insofar as citizens are guaranteed the opportunity to mount a challenge. Where such an opportunity clearly exists and standing to apply for judicial review is not in question, the right to judicial protection is respected and the formalism of TWD is justified by the principles of legal certainty, good administration of justice and procedural economy. ${ }^{25}$

It could be argued that TWD does not apply to an EU measure:

a) which in the light of a subsequent judgment of the Court of Justice has proved to violate basic fundamental rights;

b) which causes substantial injustice; and

c) about which the person concerned has complained immediately after becoming aware of the judgment of the Court.

It is an open question whether the Court of Justice might be prepared to accept such an exception. In any event, the harsh effects of TWD are alleviated by two factors. First, as will be argued below, ${ }^{26}$ TWD does not apply to criminal proceedings. Secondly, its effects are lessened where economic sanctions are limited in time. Thus, where the EU measure imposing the sanctions requires the Council to review the list at regular intervals, the Council will be under an obligation to honour the process rights established in Kadi when it renews the list. Where the freezing of funds is of indefinite duration, the issue arises whether the permanency of the sanctions may itself be contrary to Article 6 ECHR. It is submitted that there would indeed be a breach of Article 6, and possibly also of Article 8, insofar as a listed person was denied the opportunity to plead that circumstances have

\footnotetext{
23 The case law states that a party may not, by means of an action for damages, circumvent the inadmissibility of an application for annulment which concerns the same instance of illegality and has the same financial end in view: see, eg, AssiDöman, above n 14, para 62; Joined Cases C-199 and C-200/94 P Pevasa and Impesca v Commission [1995] ECR I-3709. It would thus not be possible for a listed person to obtain release of his funds or compensation equal to the amount of the funds frozen by means of an action in damages, although he could obtain compensation for any damage arising as a result of the freezing of his assets. For the chances of success of an action in damages, see T Tridimas and JA Gutierrez-Fons, above n 10 , at $702 \mathrm{ff}$.

24 See TWD, above n 17, para 13; AssiDöman, above n 14, para 57.

25 See AssiDöman, above n 14, para 61.

26 See section II.C. below.
} 
changed and that they thus no longer warrant his inclusion in the list. The indefinite duration of a freezing order appears contrary to the principle of proportionality which is embodied in Articles 6 and 8 ECHR. Support for this view may also be found in the judgment in HM Treasury $v$ Jabar Abmed, ${ }^{27}$ where the UK Supreme Court viewed the permanent character of the sanctions in issue as one of the reasons which made it incompatible with fundamental rights. It is thus submitted that, where an EU sanctions regime is of indefinite duration, a listed entity has the right to request the Council to revisit its position, and may challenge the Council's refusal to do so under Articles 263 and 265 TFEU (ex Articles 230 and 232 EC, respectively).

\section{B. Effect on third parties: The $E$ \& $F$ case}

So far, we have examined the effects of Kadi on other persons listed in Regulation 881/2002/EC. There is, however, a wider issue: what are the effects of the illegality of sanctions on third parties? The Court had the opportunity to examine this issue in $E \& F .^{28}$ The defendants in the main proceedings were members of an organisation known as DHKP-C, whose funds had been frozen pursuant to Council Regulation 2580/2001/EC. ${ }^{29}$ That Regulation had been adopted to give effect to UNSC Resolution 1373 (2001) and CFSP Common Position 2001/931. ${ }^{30}$ Article 2 of Regulation 2580/2001/EC provides for the freezing of funds of the persons included in a sanctions list which is to be determined by a Council decision. It also prohibits making available funds or other financial resources for the benefit of a person included in the list. DHKP-C was first included in the sanctions list by Council Decision 2002/334/EC. ${ }^{31}$ Its inclusion was maintained for the years 2002 to 2008 by successive Council decisions updating the list.

$\mathrm{E}$ and $\mathrm{F}$ were charged with being members of DHKP-C, organising fundraising campaigns for its benefit and transferring funds to it. The charges were based on paragraph 34(4) of the German Law on Foreign Trade, which makes infringement of EU legislative acts such as Regulation 2580/2001/EC punishable by criminal penalties. The criminal court hearing the case was uncertain as to the legality of the criminal charges. Its doubts were based

27 Above, $\mathrm{n}$ 4. See, eg, paras 5 and 39 per Lord Hope. See also R(M) v HM Treasury [2008]

2 All ER 1097.

28 Case C-550/09 E and F, judgment of 29 June 2010, nyr.

29 [2001] OJ L344/70.

30 [2001] OJ L344/93.

31 [2002] OJ L116/33. 
on the judgments of the General Court in OMPI I and related cases ${ }^{32}$ where the General Court had annulled Council decisions implementing Regulation 2580/2001/EC for breach of process rights, including the requirement to state reasons. In the light of those judgments, the criminal court doubted whether the inclusion of DHKP-C in the sanctions list was legal, since the Council had failed to state reasons for the listing of the various persons contained in the sanction list. It was, however, uncertain whether the Council decisions could be declared illegal insofar as they placed and subsequently maintained DHKP-C on the list, given that DHKP-C had not itself sought annulment of its inclusion in the list.

There was an additional complication in the case. Following the judgment of the General Court in OMPI I, the Council (by Decision 2007/445/EC ${ }^{33}$ ) had maintained DHKP-C's name in the list, but this time it sought to provide reasons for doing so. The referring court was uncertain as to whether Decision 2007/445/EC might have legitimated ex post facto the inclusion of DHKP-C in the list for the period prior to 29 June 2007 when it took effect. There were therefore two separate issues before the Court of Justice: first, whether the validity of DHKP-C's listing could be contested in the context of the criminal proceedings against $\mathrm{E}$ and $\mathrm{F}$ despite the fact that DHKP-C had not brought direct proceedings in time; and, secondly, whether a Council decision providing reasons for the inclusion of an organisation in the sanction list may legitimate ex post facto the organisation's inclusion in the list for past periods of time. Each of those issues will be examined in turn.

On the first issue, the Court of Justice held that the Council decisions implementing Regulation 2580/2001/EC could be held illegal insofar as they included DHKP-C in the sanctions list. It reasoned as follows: reaffirming TWD, it held that the right to challenge the validity of an EU measure via the preliminary reference procedure presupposes that the party in question had no right of direct action. ${ }^{34}$ It then went on to determine whether, if the defendants had brought an action for annulment of that listing, the admissibility of their action would have been beyond doubt, and came to a negative conclusion. ${ }^{35}$ It was not the defendants themselves but DHKP-C which had been placed on the sanctions list. Further, there was no information on the basis of which it could be established that the position occupied by the defendants within DHKP-C would have conferred on them the power to represent that organisation in an action for annulment. Lastly, it could not be held that the defendants were indisputably directly

32 See Case T-228/02 Organisation des Modjahedines du people d'Iran $v$ Council, [2006] ECR II-4665 (OMPI I); Case T-253/04 KONGRA-GEL [2008] ECR II46; Case T-229/02 Osman Ocalan on behalf of PKK $v$ Council [2008] ECR II-45; Case T-327/03 Stichting AlAqsa v Council [2007] ECR II-79; and Case T-47/03 Sisonv Council [2007] ECR II-79.

33 [2007] OJ L169/58.

34 E and $F$, above n 28, para 46.

35 Ibid, paras 49-50. 
and individually concerned by the listing of DHKP-C. ${ }^{36}$ It followed that, in contrast to DHKP-C, the defendants did not have an indisputable right to bring a direct action for annulment. ${ }^{37}$

Having established that the legality of the DHKP-C's inclusion in the list could be challenged, the Court of Justice went on to find that the duty to state reasons had been violated, because none of the successive Council decisions listing DHKP-C had been accompanied by a statement of reasons. As a result of the lack of reasoning, the defendants had been denied the information necessary to enable them to verify whether the inclusion of DHKP-C on the list was well-founded. They therefore did not have the opportunity to contest the accuracy and relevance of the evidence on which the listing was based, although it was one of the bases of the charges brought against them. ${ }^{38}$

Turning to the issue of retroactivity, the Court rejected the argument that the adoption of Decision 2007/445/EC could legitimate ex post facto the inclusion of DHKP-C on the list prior to the date when that decision was adopted. ${ }^{39}$ It is difficult to see how the Court could have reached any other conclusion. If Decision 2007/445/EC could remedy retroactively the lack of reasoning in the previous decisions listing DHKP-C, it would form the basis for a criminal conviction in respect of acts committed before its adoption and thus run counter to the prohibition on retroactive application of criminal law. As the Court and the Advocate-General pointed out, that prohibition applies not only to provisions which criminalise conduct, but to all provisions which form the basis for a criminal conviction. ${ }^{40}$

$36 \mathrm{Ibid}$, para 51. This is because inclusion in the sanctions list, as provided by Regulation $2580 / 2001 / E C$, is of general application. It serves, together with that regulation, to impose on an indeterminate number of persons an obligation to comply with specific restrictive measures against DHKP-C.

37 Ibid, para 52.

38 Ibid, para 56.

39 Note that the questions referred concerned only the legality of the listing of DHKP-C by successive Council decisions until the entry into force of Decision 2007/445/EC. By contrast, the legality of the latter decision and subsequent decisions by which DHKP-C was maintained in the list was not in issue in the proceedings. The Court therefore did not have the opportunity to consider whether the statement of reasons for the listing of DHKP-C provided in Decision 2007/445/EC was adequate.

$40 \mathrm{E}$ and F, above n 28, para 59; Opinion of A-G Mengozzi of 17 May 2010 in that case, para 117. See, for previous case law, Case 63/83 Kirk [1984] ECR 2689, paras 21 and 22; Case C-331/88 Fedesa and Others [1990] ECR I-4023, para 44; and Joined Cases C-387/02, C-391/02 and C-403/02 Berlusconi and Others [2005] ECR I-3565, paras 74-78. Note, however, that Decision 2007/445/EC could have retroactive effect outside the sphere of criminal law. As the General Court pointed out in Case T-256/07 People's Mojahedin Organisation of Iran v Council (OMPI II) [2008] ECR II-3019, para 65, when a measure has been annulled for procedural defects, the institution concerned is entitled to adopt afresh an identical measure, this time observing the formal and procedural rules in question, and even to give that measure retroactive effect, if that is essential to the attainment of the public interest objective pursued and if the legitimate expectations of the persons concerned are duly protected. Thus, where the inclusion of a person in the sanctions list is annulled for procedural errors, the Council has the power to adopt a new decision with retroactive effect reinstating the person concerned in the list. 
An interesting aspect of the case relates to the invocability of the grounds of annulment. The Commission and the prosecutor had submitted that the defendants could not invoke the breach of DHKP-C's procedural rights. Advocate-General Mengozzi rejected that argument, inter alia on the ground that, under the case law, the jurisdiction of the Court of Justice to give rulings on the validity of EU acts cannot be limited by the grounds on which their validity is contested..$^{41}$ Also, if that argument were accepted, it would result in denying the right which defendants generally possess to contest the legality of acts on which the charges against them are based. ${ }^{42}$ Furthermore, in the context of a preliminary reference, it is for the referring court to decide whether to pose a question on the validity of an EU act and the possible grounds of invalidity. ${ }^{43}$

In the circumstances of the case, the Court's approach was correct. It is clear that the lack of reasoning had a direct impact upon the defendants, since one of the bases of the criminal charges against them was that DHKP-C was a listed organisation. The absence of reasons, therefore, denied them the information necessary to enable them to verify whether the inclusion of DHKP-C on the list was well-founded. The judgment, however, does not necessarily stand as a general pronouncement that, where the validity of an EU measure is challenged indirectly in national proceedings, a party may invoke the breach of process rights of the persons to whom that measure is addressed. It is uncertain, for example, whether interested parties could invoke the breach of the right to a hearing of the persons included in the list. The requirement to give reasons receives preferential treatment because it has a strong public law rationale. According to standard case law, one of the objectives of the requirement to give reasons is to enable the Court to exercise its power of review. ${ }^{44}$ This explains why the Court is more willing to examine of its own motion whether the statement of reasons of a measure are adequate ${ }^{45}$ than whether the rights of defence have been respected. ${ }^{46}$

41 See Opinion of A-G Mengozzi of 17 May 2010 in Case C-550/09 E and F, above n 28, para 96.

42 Ibid, para 97.

43 Ibid, para 98.

44 Its other objectives being to give an opportunity to the parties involved of defending their rights, and to third persons of ascertaining the circumstances in which the institution concerned applied the Treaty: see, eg, Case 24/62 Germany v Commission [1963] ECR 63, 69; Case 294/81 Control Data $v$ Commission [1983] ECR 911, para 14; Joined Cases T-79/89, etc BASF AG and Others $v$ Commission [1992] ECR II-315, para 66.

45 Case 18/57 Nold $v$ High Authority [1959] ECR 41; Case 185/85 Usinor v Commission [1986] ECR 2079, para 19; Case C-166/95 P Commission v Daffix [1997] ECR I-983, para 24. The Community judicature is, however, not under a duty to raise the issue on its own motion in all cases and, depending on the circumstances, it may reject as inadmissible a plea that the contested act is insufficiently reasoned if it is not submitted in time: Case T-106/95 Fédération Française des Sociétés d'Assurances (FFSA) and Others v Commission [1997] ECR II-229, para 62.

46 See, eg, Case T-106/95 Fédération Française des Sociétés d'Assurances (FFSA) and Others $v$ Commission [1997] ECR II-229, paras 48-49; Case T-16/91 Rendo and Others $v$ Commission [1992] ECR II-2417, para 131. 
Advocate-General Mengozzi appeared to accept that the Court of Justice could review the decision on any grounds, thus suggesting that review has a universal character. A more nuanced approach would suggest that it is necessary to establish in each case whether the rule or principle of EU law breach of which is claimed before the national court confers rights on the party who seeks to invoke it. This may be viewed as an issue of standing to be decided under national law, or as an attribute of the EU principle or rule breach of which is claimed, which is to be determined by EU law. It is submitted that, in general, it is best viewed as such an attribute. The answer to the question depends upon two considerations. First, there are the objectives and scope of the process rights infringement of which is claimed: can it be said that those rights are intended to protect the rights of third parties, or do they protect only the rights of the addressee? Secondly, practical considerations must also be taken into account. Depending upon the rights in issue, it may not be possible for the Court to decide whether the process rights of the addressee have been breached in litigation where the addressee itself is not represented. Where this is not an issue, the importance of the rule that has been breached may also be a relevant consideration. Thus, the Court may be tempted to take the view that fundamental rights have a universal application, in that they can be invoked by any party whose legal position is adversely affected as a result of their breach.

\section{Indirect challenge in criminal proceedings}

A wider issue which arises in this context is whether TWD applies to criminal proceedings. Is a person subject to a criminal charge precluded from contesting the legality of an EU measure which forms the basis of the charge if he failed to challenge it directly? This is of some practical importance. The Treaty of Lisbon increases the presence of the EU in the sphere of criminal law, and thus makes it more likely that EU measures will be used to found national criminal legislation. In most cases, the charges will originate in a measure of general application in relation to which the standing of individuals is uncertain, so that TWD will be no obstacle. As $E$ \& $F$ illustrates, however, it is not inconceivable that a measure in relation to which standing can easily be established may also be the basis for criminal proceedings.

In $E \& F$, the Court reiterated the application of TWD as a general rule and found that it did not apply, not because of the criminal nature of the proceedings but because it had not been established beyond doubt that the defendants had standing to mount a direct challenge. The Court expressly stated that DHKP-C had an indisputable right to bring a direct action for the annulment of its listing. ${ }^{47}$ The implication may thus be drawn that, had

$47 E$ and $F$, above $\mathrm{n} 28$, para 52. 
a person included in the sanctions list sought to challenge its inclusion indirectly, it would have run into the TWD barrier, irrespective of the nature of the proceedings in the context of which the challenge was made. The case remains, however, that the Court of Justice did not examine this aspect specifically. The fact that it could have used the criminal nature of the proceedings to exclude the application of TWD does not equate with a finding that TWD applies to such proceedings, especially since the questions referred did not directly raise that issue.

There are powerful arguments against the application of TWD in criminal proceedings. The underlying premise of that principle is that the right to judicial protection is not without limits, and that legal certainty and finality, as expressed in the existence of time limits, are also pivotal aspects of the rule of law. Thus, although procedural exclusivity may in some cases have harsh consequences, overall these are outweighed by the advantages of legal certainty, the finality of disputes, and the integrity and stability of the legal system. This cost-effectiveness balance, however, changes where criminal charges are put into the mix. In such a case, the scales tip in favour of judicial protection. Indeed, Advocate-General Mengozzi expressed strong doubts about the applicability of TWD in criminal proceedings. He opined that legal certainty is not an absolute requirement and should not take precedence over the right of citizens to defend themselves in criminal proceedings by contesting the legality of the provisions on which the charges are based, especially where such provisions run counter to fundamental rights. ${ }^{48}$ It is submitted that the extension of TWD to criminal proceedings would undermine the commitment of the EU legal order to fundamental rights and may also run counter to Article 6 ECHR. ${ }^{49}$

48 See Opinion of A-G Mengozzi, ibid, paras 86-87.

49 The case law of the European Court of Human Rights (ECtHR) does not appear to have dealt specifically with this issue. More generally, it accepts that reasonable limitation periods in civil proceedings serve legal certainty and finality, and are compatible with Art 6 ECHR, although an unduly short limitation period may give rise to a violation: see, eg, Perez de Rada Cavanilles v Spain (1998) 29 EHRR 109; Dobbie v United Kingdom, App no 28477/95, noted [1997] EHRLR 166. The case law has also accepted that although Art 6 ECHR does not guarantee a right of access to a court with power to invalidate or override a legislative measure, it does require that where a measure, albeit not formally addressed to an individual, affects his civil rights or obligations, whether by reason of certain attributes peculiar to him or by reason of a factual situation which differentiates him from all other persons, Art 6(1) may require that the substance of that measure is capable of being challenged before a court or tribunal: Posti and Rabko $v$ Finland, App no 27824/95 (2003) 37 EHRR 6, judgment of 24 September 2002, para 53. These authorities are not of direct relevance to the situation under examination. It is submitted that the extension of TWD to criminal proceedings may well be viewed as a restriction of the right of access to court which is disproportionate and runs counter to the right to equality of arms, since the defendant is deprived of the opportunity to dispute the evidence and the grounds raised against him. It may also be a violation of the right to non-discrimination provided in Art 14 ECHR. 
review of the legality of the measure on which the charges are based, ${ }^{53}$ and are in fact required to do so where an objection of illegality is raised. ${ }^{54}$

\section{VALIDITY AND INTERPRETATION OF REGULATION 881/2002/EC}

\section{A. Issues of validity}

The judgment in Kadi was followed by the judgments of the CFI (now the General Court) in Othman ${ }^{55}$ and of the Court of Justice itself in Hassan and Ayadi. ${ }^{56}$ Both cases related to sanctions lists prescribed by the UN Sanctions Committee and implemented by Regulation 881/2002/EC. ${ }^{57}$ In Othman, ${ }^{58}$ the applicant had initiated proceedings in 2001, but they were suspended pending the outcome of the judgment in Kadi. Upon resumption of the proceedings, the General Court found for the applicant. Given the judgment of the Court of Justice in Kadi, it is not possible to see how the General Court could have reached any other conclusion. The judgment of the General Court was different, however, in one respect. The General Court denied the Council's request to maintain temporarily the effects of the contested Regulation. It did so on two grounds. ${ }^{59}$ First, it held that the period that had already elapsed since the delivery of the Court of Justice's judgment in Kadi far exceeded the maximum period of three months allowed by the Court of Justice in that case to enable the Council to remedy the breach of process rights. Since the applicant's situation was comparable to those of the appellants in Kadi, the Council could not have been unaware that it should have taken the same steps in relation to the applicant as those required in Kadi.

The General Court gave a second reason which made it inappropriate to preserve the effects of the contested Regulation. It pointed out a difference between a Court of Justice judgment and a General Court judgment. Under Article 60 of the Statute of the Court of Justice, General Court rulings declaring a regulation to be void take effect only from the date of expiry of

53 See Judgment of the Greek Court of Cassation No 782/79.

54 Art 62 of the Code of Criminal Procedure also provides that a judgment of a civil court on an issue which relates to a criminal trial does not bind the criminal court and is assessed independently at its discretion. This applies by analogy also to administrative law issues which are relevant to a criminal trial, although a criminal court is bound by a ruling of an administrative court declaring an administrative act invalid. See further E Spiliotopoulos, Elements of Greek Administrative Law, 9th edn (Athens, Sakkoulas, 1999) 115; A Karras, Criminal Procedure, 2nd edn (Athens, Sakkoulas, 1998) 113ff.

55 Case T-318/01 Othman v Council [2009] ECR II-1627.

56 Joined Cases C-399 and C-403/06 P Hassan and Ayadiv Council and Commission, judgment of 3 December 2009, nyr.

57 Above $\mathrm{n} 2$.

58 Above n 55.

59 Ibid, paras 97-98. 
the two-month period allowed for appeal to the Court of Justice or, if an appeal has been brought, as from the date of dismissal of the appeal. Thus, in any event, in addition to the time elapsed since the delivery of the Court of Justice's judgment in Kadi, the Council had had an additional period of at least two months in order to remedy the infringements found.

The General Court's approach suggests that the power to maintain in force the effects of a measure vitiated by illegality is to be used sparingly. It is, after all, an exceptional power, which allows an illegal measure to produce effects on a temporary basis in order to satisfy a higher interest of justice. One may have some sympathy with the Council's position in Kadi, since the sanctions lists originated from the UN and it would not be possible for the Council to adduce any evidence or provide a statement of reasons to the applicant without first referring the matter to the Sanctions Committee, which the Council appears to have done. ${ }^{60}$ Nevertheless, the obligation to comply with process rights cannot be viewed merely as a 'best efforts' obligation. It is an absolute one. Otherwise, one would run the risk of nullifying the substantive findings of the judgment by delaying compliance with the ruling for an indefinite period of time. Compliance with the judgments of the Court of Justice cannot be at the discretion of a third party-in this case, the UN Sanctions Committee.

In Hassan and Ayadi, ${ }^{61}$ the applicants' assets had been frozen by Regulation 881/2002/EC. Their actions for annulment pre-dated the Court of Justice's judgment in Kadi. At first instance, ${ }^{62}$ the General Court rejected their actions on the basis of reasoning similar to that in its judgment in Kadi. ${ }^{63}$ When the applicants appealed against the General Court judgment, the case raised an interesting issue of procedure. Following the judgment of the Court of Justice in Kadi, the Commission adopted Regulation 954/2009/EC, ${ }^{64}$ which amended Regulation 881/2002/EC, and decided, after hearing the applicants, to include them again in the sanctions list with retroactive effect. The question therefore arose whether, in view of the withdrawal of Regulation 881/2002/EC and its retroactive replacement by Regulation 954/2009/EC, it was still necessary to rule on the appeal.

\footnotetext{
60 Ibid, paras 72 and 73 .

61 Above n 56.

62 Case T-40/04 Hassanv Council and Commission [2006] ECR II-52; Case T-253/02 Ayadiv Council [2006] ECR II-2139.

63 The General Court held that, since the sanctions list originated in UNSC resolutions, the General Court did not have jurisdiction to examine the compatibility of Regulation 881/2002/ EC with fundamental rights as they are protected in the EU legal order but only as they are recognised under jus cogens, and that, in the circumstances, the requirements of jus cogens had been met.

64 [2009] OJ L269/20.
} 
The Court of Justice answered in the affirmative. It held that the adoption of Regulation 954/2009/EC could not be regarded as equivalent to annulment 'pure and simple' of Regulation 881/2002/EC. ${ }^{65}$ Regulation $954 / 2009 / \mathrm{EC}$ had kept the names of the appellants in the sanctions list with retroactive force, so that their assets continued to be frozen for the period for which Regulation 881/2002/EC was applicable, although the purpose of their actions was precisely to have their names removed from the sanctions list. The adoption of Regulation 954/2009/EC could not, therefore, be considered to be a fact occurring after the judgments under appeal and capable of rendering the appeals devoid of purpose. ${ }^{66}$ The Court further observed that Regulation 954/2009/EC was not yet definitive, in that it could be the subject of an action for annulment. It therefore remained possible that Regulation 881/2002/EC might come back into force in relation to the appellants in the event that Regulation 954/2009/EC was successfully challenged. ${ }^{67}$

On the substance, the Court of Justice allowed the appeal, on the ground that the General Court's reasoning was marred by the same errors in law as those of its judgment in Kadi, and it proceeded to annul Regulation $881 / 2002 / \mathrm{EC}$ insofar as it applied to the appellants. In this case, the Court of Justice did not need to maintain the effects of the regulation in force since it had already been replaced by Regulation 954/2009/EC.

\section{B. Issues of interpretation}

Whilst Kadi, Othman and Hassan questioned the validity of Regulation 881/2002/EC, M v HM Treasury gave rise to issues pertaining to its interpretation. ${ }^{68}$ The Court was called upon to interpret Article 2(2) of the Regulation, which states as follows:

No funds shall be made available, directly or indirectly, to or for the benefit of, a natural or legal person, group or entity designated by the Sanctions Committee and listed in Annex I.

Article $2 \mathrm{a}$ of the Regulation, which was added to give effect to UNSC Resolution 1452 (2002), provides for an exception to the effect that the prohibition of Article 2(2) does not apply to funds which the competent

65 Hassan and Ayadi, above n 56, para 61.

66 Ibid, para 62.

$67 \mathrm{Ibid}$, para 63 . On that ground, the Court distinguished the contested regulation from the measure at issue in its earlier order in Case C-123/92 Lezzi Pietro v Commission [1993] ECR I-809.

68 Case C-340/08 The Queen on the application of $M$ and Others $v$ HM Treasury, judgment of 29 April 2010, nyr ( $M v$ HM Treasury). For a previous case pertaining to the interpretation of the sanctions regime, see Case C-117/06 Möllendorf-Niehuus [2007] ECR I-8361. 
authorities of the Member States have determined to be, with the approval of the Sanctions Committee, necessary to cover basic expenses, such as payments for food, rent and medical treatment. The UK Treasury decided that various social security benefits, including income support and housing benefit, payable to spouses of listed persons, were caught by the prohibition in Article 2(2). The rationale of the Treasury was that, because the above benefits might be used to cover the basic needs of households to which listed persons belong, they are made indirectly available for their benefit within the meaning of Article 2(2). Consequently, the Treasury decided that such benefits could be paid only if they were covered by an exception under Article $2 \mathrm{a}$, which took the form of a licence. Such licences were issued to various public authorities, permitting them to continue to pay social benefits to spouses of listed persons, subject to certain conditions. The House of Lords considered that the Treasury's licensing system made for an intrusive regime that was not required by Article 2(2), and sought a preliminary reference on whether the payment of social security benefits to the spouses of listed persons was caught by the prohibition in Article 2(2).

The Court of Justice answered in the negative. It identified differences in the various language versions of the Regulation and held that a literal interpretation of Article 2(2) was not by itself capable of establishing its meaning. It noted that, in the English version, the prohibition in Article 2(2) included making funds available indirectly for the benefit of a listed person, and would thus cover the payment of a social security benefit to the spouse of a listed person. Whilst that interpretation was also supported by the Hungarian, Dutch, Finnish and Swedish versions, other groups of languages did not countenance it. ${ }^{69}$ The Court of Justice also identified differences in the language versions of the UNSC resolutions to which the Regulation was intended to give effect. In view of such divergences, it held that Article 2(2) must be interpreted in the light of the purpose and the general scheme of the legislation of which it formed part, and account must also be taken of the substance of Resolution 1390 (2002), to which it intended to give effect. ${ }^{70}$

The Court held that, in the light of the objectives of the Regulation, the sanctions applied only to those assets that could be turned into funds, goods or services capable of being used to support terrorist activities. ${ }^{71}$ Essentially, in the circumstances of the case, the Treasury had followed an

69 The Court held that in the Spanish, French, Portuguese and Romanian texts, the prohibition referred to the 'use' of funds for the benefit of a listed person. These versions did not support the argument that, by making social security benefits available to the spouses of listed persons, the authorities used those funds for the benefit of the latter. A third group of language versions, such as those in German and Italian, did not fall within either of the above categories and used their own terminology. See $M v$ HM Treasury, above n 68, para 43.

70 Ibid, para 49.

71 Ibid, paras 54-58. 
erroneous interpretation of Article 2(2). Its construction was not based on any danger whatsoever that the social security benefits might be diverted in order to support terrorist activities. It had not been argued that the spouses concerned handed over those funds to a listed person instead of allocating them to their basic household expenses. Such a misappropriation of funds would, in any event, be covered by Article 2(2) and constitute an offence punishable under national criminal law. It was also hard to imagine how those funds could support terrorist activities, since the benefits were fixed at a level intended to meet only strictly vital needs. ${ }^{72}$

Thus, in $M v H M$ Treasury the Court was led to a narrow interpretation of Article 2(2) on the basis of a teleological interpretation. It is notable, however, that it did not look at the objectives of the Regulation before establishing textual ambiguity in the light of the linguistic variations of Article 2(2). Its greater reliance upon the text is attributable to the fact that the measure in issue was a regulation, which needs to be applied uniformly throughout the EU.

Although human rights considerations are present in the judgment, they are less prominent than in the Kadi line of cases. The Court gave an additional reason in favour of a narrow interpretation of Article 2(2). Applying the presumption of constitutional interpretation, it held that, in construing EU legislation, preference should be given, as far as possible, to the interpretation which renders the provision consistent with the general principles of EU law and, more specifically, the principle of legal certainty. ${ }^{73}$ That principle requires that legislation which imposes economic sanctions and involves the imposition of penalties for their infringement must be clear and precise so that the persons concerned, including third parties such as the social security bodies involved in the main proceedings, may know unambiguously their rights and duties. A construction which would bring the payment of social security benefits within the scope of Article 2(2) would engender legal uncertainty, in particular in triangular situations where funds are made available not to a listed person but someone close to him. ${ }^{74}$

What are the implications of the judgment? Since the payment of a social security benefit is not covered by the prohibition in Article 2(2), it follows that it cannot be made subject to a licence under UK implementing measures. It must be paid to the spouse freely, without the need to be covered by the exception in Article $2 \mathrm{a} .{ }^{75}$ If, however, instead of being allocated to

72 Ibid, paras 59-61.

$73 \mathrm{Ibid}$, para 64.

${ }_{74} \mathrm{Ibid}$, paras 64-66.

75 The Court also stated that the narrow interpretation of Art 2(2) did not render the exception in Art 2a superfluous. That exception applies in cases where funds are made available directly or indirectly to a listed person and not to a third party, since, in such cases, the listed person can decide how to use those funds, and this in turn involves a danger of their being diverted for terrorist purposes: see ibid, para 71. 
meeting basic household or other permissible expenses, the benefit was diverted in order to support terrorist activities, that would be a violation of the prohibition in Article 2(2) and carry criminal penalties under the UK implementing legislation. ${ }^{76}$

An interesting question which arises here is this: can the Treasury introduce a licensing system not on the basis that the payment of a social security benefit to a spouse is prohibited under Article 2(2), but in order to enforce the prohibition in that article, ie as a mechanism to ensure that such payments cannot be diverted to terrorist activities? The answer appears to be in the affirmative. It would then be a matter of examining the conditions to which payment of the benefit was made subject. The judgment in $M v H M$ Treasury should not be read as prohibiting a licensing system but as allowing one insofar as it is necessary to ensure compliance with the prohibition in Article 2(2), and subject to respect for human rights and the principle of proportionality. The unspoken principles underlying the reasoning of the Court are respect for human dignity and the right to family life. The conditions to which payment of the social security benefit was subject appeared too harsh and in breach of the right to dignity and the right to family life, although the Court did not expressly state this. ${ }^{77}$

\section{Sanctions against nuclear proliferation}

Othman and Hassan contrast with Melli Bank, ${ }^{78}$ where the General Court upheld the freezing of assets of a UK bank in implementation of a sanctions regime seeking to avoid the proliferation of nuclear weapons. The case raised interesting issues pertaining, inter alia, to the vigour of judicial review, the Council's discretionary powers and the risk assessment carried out by the General Court.

The origins of the case lie in sanctions imposed by the UNSC on Iran. Melli Bank plc was a UK subsidiary of BMI, an Iranian bank controlled by the Iranian State. The assets of both banks were frozen by Council Decision 2008/475/EC, ${ }^{79}$ adopted on the basis of Council Regulation 423/2007/EC ${ }^{80}$

76 Ibid, paras 58-59.

77 These conditions were the following: (a) the benefits had to be paid into a bank account from which the spouse concerned could draw only $£ 10$ in cash for each member of the household; other payments had to be made by debit card; (b) the spouse concerned had to send a monthly account to the Treasury detailing all her expenditure and enclosing receipts for the goods purchased and a bank statement; (c) the licence included a warning to the spouse that it was a criminal offence to make funds available to her husband since he was a listed person. See the Al-Qa'eda and Taliban (United Nations Measures) Order 2002 (SI 2002/111), Art 7.

78 Joined Cases T-246 \& T-332/08 Melli Bank plc v Council [2009] ECR II- 2629 (Melli Bank).

79 [2008] OJ L163/29.

80 [2007] OJ L103/1. 
which, in turn, gave effect to UNSC Resolution 1737 (2006). Article 7(1) of Regulation 423/2007/EC provides for the freezing of funds of the persons and entities designated by the Security Council. Article 7(2) extends the sanctions to persons and entities associated with Iran's nuclear programme. More specifically, Article 7(2)(a) and (b) provide for the freezing of funds of entities which have been identified as being engaged in, directly associated with or providing support for, Iran's nuclear activities. Furthermore, Article $7(2)(\mathrm{d})$ provides for the freezing of funds of a legal person owned or controlled by an entity referred to under Article 7(2)(a) or (b). The assets of BMI were frozen under Article 7(2). The freezing order was extended to Melli Bank's assets on the basis of Article 7(2)(d), ie as an entity owned or controlled by BMI.

Melli Bank argued that Article $7(2)(\mathrm{d})$ did not require the Council to freeze automatically the assets of all legal persons owned or controlled by entities whose funds had been frozen by virtue of Article 7(2)(a) or (b), and that if Article $7(2)(\mathrm{d})$ was interpreted to remove all discretion from the Council, it would run counter to the principle of proportionality. The General Court rejected this argument based on a textual analysis and a teleological interpretation founded on a cautious assessment of risk.

The General Court held that Article 7(2)(d) uses peremptory language, which states that all funds belonging to an entity owned or controlled by a person engaged in nuclear proliferation 'shall be frozen'. It followed that the freezing of funds was obligatory. The Council was under an obligation to undertake an evaluation in order to determine whether an entity is 'owned or controlled' by a person identified as engaged in nuclear proliferation, but, once such ownership or control was ascertained, the Council enjoyed no discretion. ${ }^{81}$ The General Court held that this interpretation was also in line with the objectives of the Regulation, which were to prevent nuclear proliferation and, more generally, maintain international peace and security. ${ }^{82}$

The General Court further held that in determining whether an entity was owned or controlled by another body, the Council had to take into account all the relevant aspects of the specific case, such as the degree of operational independence of the entity or the possible effect of the supervision to which it was subject by public regulators. In contrast, the nature of that entity's activities and the possible lack of any link between those activities and nuclear proliferation were not relevant criteria. Applying a risk-averse approach, the General Court held ${ }^{83}$ :

When the funds of an entity identified as being engaged in nuclear proliferation are frozen, there is a not insignificant danger that that entity may exert pressure

${ }^{81}$ Melli Bank, above n 78, paras 63-65.

82 Ibid, para 66.

83 Ibid, para 103. 
on the entities it owns or controls in order to circumvent the effect of the measures applying to it, by encouraging them either to transfer their funds to it, directly or indirectly, or to carry out transactions which it cannot itself perform by reason of the freezing of its funds. That being so, it must be considered that the freezing of the funds of entities owned or controlled by an entity identified as being engaged in nuclear proliferation is necessary and appropriate in order to ensure the effectiveness of the measures adopted vis-à-vis that entity and to ensure that those measures are not circumvented.

The General Court also found that other, less restrictive mechanisms might not guarantee fulfilment of the objectives of the Regulation. Thus, the existence of rules prohibiting the carrying out of transactions with entities identified as being engaged in terrorism was not in itself a guarantee that such transactions would not take place. Neither could the reinforcement of supervision or financial transparency fill the risk gap. ${ }^{84}$

There are apparent similarities between Mv HM Treasury and Melli Bank. Both cases involved the imposition of sanctions on persons associated with the primary targets of the sanctions regime. The similarities are superficial, however, whilst the differences are striking. In $M v H M$ Treasury, the funds in question were insignificant; in Melli Bank, human dignity, personal freedom and the right to life were not an issue. Melli Bank involved a banking group controlled by the State which was the subject of sanctions. The General Court was correct to apply a high standard of scrutiny to the existence of ownership or control, but a lower standard when addressing the legislature's assessment of risk.

The General Court opted for a substantive rather than formal interpretation of the concept of control. It held that ownership of a company by another is not in itself a determinative criterion. It had to be examined whether, because the applicant was owned by BMI, there was a considerable likelihood that it might be prompted to circumvent the sanctions adopted against its parent company. ${ }^{85}$ The General Court sought guidance from competition law as to when the conduct of a subsidiary may be imputed to a parent undertaking, ${ }^{86}$ and placed particular emphasis upon the powers of the parent to appoint the directors of the subsidiary. It held that the fact that one entity is wholly owned by another generally means that the latter is entitled to appoint the directors of the former, and it may therefore exercise actual control over its management and its staff. ${ }^{87}$ Whilst the General Court left the door open for the possibility that the freezing of funds of a company which is owned by a listed person may not be justified, this would

84 Ibid, paras 71,17 and 108.

85 Ibid, para 121.

86 See ibid, para 121, referring to Case 48/69 Imperial Chemical Industries $v$ Commission [1972] ECR 619, para 133, and Case C-73/95 P Viho $v$ Commission [1996] ECR I-5457, para 16.

${ }_{87}$ Melli Bank, above n 78, para 123. 
occur only in 'extraordinary circumstances' ${ }^{88}$ The fact that the applicant was wholly owned by BMI created a presumption that was very difficult to rebut and which the applicant failed to displace in the circumstances. Thus, the fact that BMI did not intervene in the day-to-day running of the applicant was of no relevance since it did not affect the influence exerted by BMI, directly or indirectly, over the applicant's staff. ${ }^{89}$ The fact that the applicant had complied with all the restrictive measures and the applicable sanctions was also irrelevant. Likewise, the dissuasive nature of the penalties to which the members of the applicant's staff would be exposed was insufficient, since there was a risk that the violation of the sanctions could be disguised by the use of intermediaries. In short, the General Court considered that ex post facto means of intervention were no substitute for a strict preventative regime.

The General Court also upheld the autonomy of the Council's power to impose economic sanctions under Article 7(2). It will be remembered that Article 7(1) of the Regulation provides for the freezing of funds of persons designated by the UN Security Council. The General Court held that Article $7(2)$ was independent of the adoption of economic sanctions by the UNSC, its purpose being to enable the Council to adopt sanctions against entities that were not the subject of similar measures decided by the Security Council. This had two implications. First, it meant that the compatibility of Article 7(2)(d) with the principle of subsidiarity could not be assessed by reference to the relevant UNSC Resolution. Secondly, the applicant could not claim that the imposition of sanctions on it under this subsection unjustifiably equated it with entities on which the Security Council had imposed sanctions since the criteria for their imposition in each case were different. ${ }^{90}$

The General Court considered that the statement of reasons provided by the Council, although 'exceptionally concise', was sufficient to satisfy the requirement of reasoning. It also rejected that the right to property and the right to carry on an economic activity had been breached, recalling that they are not absolute prerogatives and that the importance of combating nuclear proliferation was such as to justify substantial negative consequences. ${ }^{91}$

Melli Bank suggests a more nuanced approach to the assessment of risk than other cases on economic sanctions. However, the material differences between Melli Bank and those cases concerning the imposition of sanctions against suspected terrorists are the legislative background of the sanctions regime, the undisputed proximity of the applicant with the main target of sanctions and the lack of engagement of civil liberties. The case had more

\footnotetext{
88 Ibid, para 124.

89 Ibid, para 125.

90 Ibid, paras 103 and 138.

91 Ibid, paras 111-12.
} 
to do with substantive policies than with process rights, and the General Court was correct to defer to the choices of the Council.

\section{THE UK SUPREME COURT AND THE SEARCH FOR 'OLDER, NOBLER, MORE ENDURING VALUES'}

The UN sanctions regime has also given rise to important issues pertaining to the rule of law in English courts. ${ }^{92}$ It is fitting that the first case heard by the new Supreme Court of the United Kingdom raised issues pertaining to constitutionalism, human rights and the separation of powers. In Jabar Abmed, ${ }^{93}$ the facts were that the Treasury had frozen the funds of the appellants on the basis of delegated legislation passed to give effect to UNSC resolutions. The appellants fell into two groups. Those in the first group had been classified as designated persons under the Terrorism (United Nations Measures) Order 2006 (SI 2006/2657) ('the TO') which had been adopted to give effect to UNSC Resolution 1373 (2001). Those in the second group had had their resources frozen under the Al-Qaida and Taliban (United Nations Measures) Order 2006 SI 2006/2952) ('the AQO') as persons whose names appeared in the UN Sanctions Committee List. ${ }^{94}$ That list had been adopted by the Sanction Committee under UNSC Resolution 1333 (2000), which required UN Member States to freeze the funds of Osama bin Laden, the Al-Qaeda network and all other individuals or entities associated with them.

Both the TO and the AQO had been made by the Treasury under powers conferred by section 1 of the United Nations Act 1946 by which the UK gave effect to the UN Charter. Section 1 enables the Government to take, by Order in Council, any measures which are 'necessary or expedient' to implement UNSC resolutions adopted under Article 41 of the Charter. The fundamental issue in the case was whether the Treasury had power under section 1 to introduce economic sanctions by means of an Order in Council. The Supreme Court answered in the negative, applying a separation of powers rationale and relying upon the principle of legality. At the heart of the Court's distrust lay the fact that orders made under section 1 of the

92 The quote in the heading comes from Lord Bingham, 'The Case of Liversidge $v$ Anderson: The Rule of Law Amid the Clash of Arms' (2009) 43 The International Lawyer 33, 38, where he stated: '[W]e are entitled to be proud that even in that extreme national emergency there was one voice-eloquent and courageous-which asserted older, nobler, more enduring values: the right of the individual against the state; the duty to govern in accordance with law; the role of the courts as guarantor of legality and individual right; the priceless gift, subject only to constraints by law established, of individual freedom.' It was cited with approval by Lord Hope in HM Treasury $v$ Mohammed Jabar Ahmed and others [2010] UKSC 2 (Jabar Ahmed), at [6].

93 Above $n 92$.

94 One of the appellants, identified as appellant G, had been designated under both the TO and the AQO. 
1946 Act are not subject to any Parliamentary scrutiny. They are simply laid before Parliament for information; the UK Parliament does not have any input as to their content. The judgment raised a number of issues, and the reasoning of the Supreme Court calls for detailed consideration. The two pieces of delegated legislation, the TO and the AQO, give rise to different issues and should be examined separately.

\section{A. The Terrorism (United Nations Measures) Order 2006}

The TO was introduced to give effect to UNSC Resolution 1373 (2001), paragraph $(\mathrm{c})$ of which required States to freeze the funds and other financial resources of persons who commit, or attempt to commit, terrorist acts, or participate in or facilitate the commission of terrorist acts. The TO empowered the Treasury to freeze the funds, inter alia, of any person where it had 'reasonable grounds for suspecting' that the person was involved in the commission of terrorist acts. The question was whether, by extending the sanctions to such suspects, the Treasury had exceeded the powers granted to it under section 1 of the 1946 Act.

The Supreme Court gave an affirmative reply. The starting point of its reasoning was the principle of legality. Under this principle, as articulated by Lord Hoffmann in Simms, ${ }^{95}$ where Parliament intends to legislate contrary to human rights, it has to use clear and unambiguous language. In the absence of express language or necessary implication, the courts will presume that the general words of a statute are intended to be subject to the basic rights of the individual. ${ }^{96}$ This dictated a narrow interpretation of the 1946 Act. Given the harsh effects of the freezing regime on human rights, the TO was found to be beyond the scope of the 1946 Act.

Lord Hope stated that since the UNSC Resolution 1373 (2001) was not phrased in terms of reasonable suspicion and left the standard of proof to the Member States to decide, it was not necessary to introduce the reasonable suspicion test in order to comply with the Resolution. Lord Phillips agreed that the TO was beyond the scope of the 1946 Act. After reviewing the wording of Resolution 1373 and other UNSC resolutions, he came to the view that Resolution 1373 did not require expressly or by implication the freezing of the assets of those who were merely suspected of criminal offences. ${ }^{97}$ All of their Lordships agreed that the consequences of the freezing of assets were dire, and therefore the expediency test of section 1 was not met. Lord Hope

$95 R v$ Secretary of State for the Home Department, ex parte Simms [2000] 2 AC 115, 131; see also $R v$ Secretary of State for the Home Department, ex parte Pierson [1998] AC 539, 573 per Lord Browne-Wilkinson.

96 Ex parte Simms, above n 95, 131.

97 Jabar Abmed, above n 92, at [137]. 
stated that the powers of the Treasury were draconian and struck 'at the very heart of the individual's basic rights to live his own life as he chooses'. ${ }^{98}$ Notably, he endorsed Sedley LJ's dictum in the Court of Appeal that the sanctions regime interfered not only with the economic freedoms of the individuals involved, but also, ultimately, with their freedom of movement. Designated persons effectively became 'prisoners of the State'.${ }^{99}$ Lord Rodger stated that if measures which affect very basic rights of the individual are to be taken, it is for Parliament to deliberate and determine that the benefits of giving the Treasury such powers outweigh the potential disadvantages, and that it is therefore expedient to adopt such measures to fulfil the obligations arising from UNSC Resolution $1373 .{ }^{100} \mathrm{He}$ considered, however, that section 1 of the 1946 Act would authorise the Government to make an Order in Council, even with these far-reaching effects, provided that it had only a limited life-span and was replaced, as soon as practically possible, by equivalent legislation passed by Parliament. In this way, the United Kingdom could promptly fulfil its obligations under the United Nations Charter. ${ }^{101}$

Some aspects of the Supreme Court's reasoning are particularly instructive. Lord Hope took into account that other UN Member States had introduced measures to comply with UNSC resolutions through primary legislation which had included safeguards, and had not found it necessary to rely exclusively upon unlimited delegation of powers to the executive. ${ }^{102}$ $\mathrm{He}$ also noted that the Anti-Terrorism, Crime and Security Act 2001, which had been enacted in the aftermath of the events of $9 / 11$, made provision for freezing orders which were more precisely worded and contained various safeguards. The orders made under the 2001 Act were subject to the affirmative resolution procedure and ceased to have effect after two years. He stated that the powers given under that Act and orders passed to implement it would have enabled the Government to comply with the UNSC resolutions.

\section{B. The Al-Qaida and Taliban (United Nations Measures) Order 2006}

The applicants whose resources had been frozen on the basis of the AQO were in a different position, in that they had been subject to freezing orders not on the basis of a reasonable suspicion, but because their names had been included in the list maintained by the UN Sanctions Committee set up by UNSC Resolution 1267 (1999). Here, the Treasury had not gone

\footnotetext{
98 Ibid, at [60].

99 Ibid, at [125].

100 Ibid, at [174].

$101 \mathrm{Ibid}$, at [176].

$102 \mathrm{Ibid}$, at [50].
} 
beyond what was strictly required to comply with the UNSC Resolution. The applicants argued that:

a) the AQO was unlawful because it breached Articles 6 and 8 ECHR, and Article 1 of Protocol 1 to the ECHR; and

b) the AQO was ultra vires section 1 of the 1946 Act because there was no judicial remedy against the 1267 Committee.

The first claim was unanimously rejected while the second was accepted.

The claim that the AQO was unlawful because it breached the European Convention was rejected essentially for two reasons. First, all of their Lordships rejected the argument that the validity of the AQO could be tested by reference to the articles of the ECHR on the ground that, under Article 103 of the UN Charter, obligations under the Charter take precedence over any other obligations arising under international law. The Supreme Court thus fully endorsed the judgment of the House of Lords in Al-Jedda $a^{103}$ and Lord Bingham's dictum to the effect that, if there were a conflict between the requirements of a UNSC resolution and the requirements of the European Convention, English courts would have no option but to give primacy to the former. Secondly, there was no conclusive proof that the European Court of Human Rights would itself find a breach of the Convention. Lord Phillips, in particular, read the judgment in Behrami ${ }^{104}$ as suggesting that the European Court of Human Rights was prepared to recognise the primacy of obligations under the UN Charter over Convention obligations. ${ }^{105}$

The appellant also argued that the AQO was contrary to rights emanating from the common law, namely the right to peaceful enjoyment of property and the right of unimpeded access to a court, neither of which could be interfered with except by clear legislative words. Those rights emanated from common law and therefore their application remained unaffected by Article 103 of the UN Charter, which provides for primacy only over international obligations. This argument proved successful.

Lord Hope accepted that the AQO was beyond the scope of section 1 of the 1946 Act because it exceeded the threshold of permissible interference with fundamental rights. The procedure for listing and de-listing persons before the UN Sanctions Committee did not meet the basic standards of natural justice and procedural fairness. Listed persons were not given reasons for their listing. It was not clear who the members of the Committee were, what rules of evidence they applied or what, if any, degree of independence they enjoyed. In adopting the 1946 Act, Parliament could not have

$103 R$ (Al-Jedda) $v$ Secretary of State for Defence [2008] AC 332.

104 Joined Cases 71412/01 Behrami and Behrami $v$ France, and 78166/01 Saramativ France, Germany and Norway (2007) 45 EHRR SE10.

105 Jabar Ahmed, above n 92, at [93]-[98]. 
intended to authorise such extensive interference with fundamental rights by a procedure which avoided Parliamentary scrutiny. ${ }^{106}$ Lord Phillips noted that the UN had gone some way towards addressing human rights concerns. United Nations Guidelines made provision for notifying a listed individual of those parts of a Member State's statement of the case against him that the State considered could publicly be released. Further, UNSC Resolution 1730 made express provision for de-listing. Those provisions, however, fell far short of satisfying the right of access to a court and of fulfilling the requirement for reasoning. ${ }^{107}$

Lord Brown was the only partially dissenting voice, coming to the conclusion that the TO should be struck down but that the AQO should stand. In his view, the two orders could be distinguished. The TO, by extending the sanctions to persons reasonably suspected of association with terrorism, went beyond what was necessary to give effect to UNSC Resolution 1373. The AQO, by contrast, implemented faithfully the UNSC resolutions to which it sought to give effect. ${ }^{108}$ Lord Brown accepted that the AQO was contrary to fundamental principles of human rights but viewed this as the inevitable result of UNSC Resolution 1267. He argued that interference with human rights should be subject to Parliamentary approval because, that way, it is made subject to political control and Parliament pays the 'political cost' due for interfering with the basic freedoms of the individual. But in this case the political cost rationale did not apply. Given the primacy of UN resolutions under Article 103 of the Charter and the unambiguous obligations flowing from UNSC Resolution 1267, 'there could surely be no political cost in doing what, unless we were flagrantly to violate our UN Charter obligations, the UK had no alternative but to do' ${ }^{109}$ This somewhat functional approach to the principle of legality was rightly rejected by Lord Rodger, who stressed the value of transparency and political control. In his view, the essential issue was that severe restrictions upon human rights should not pass unnoticed in the Parliamentary process and should be decided by the legislature rather than the executive. ${ }^{110}$

\section{Assessment of the judgment}

The judgment in Jabar Abmed raises a number of important issues, not all of which can be examined within the confines of this chapter. Suffice it

\footnotetext{
106 Ibid, at [77]-[80].

107 Ibid, at [149].

108 Ibid, at [199].

109 Ibid, at [204].

$110 \mathrm{Ibid}$, at [186].
} 
here to explore some aspects pertaining to the rule of law and some issues concerning the relevance of EU law.

The Supreme Court appeared to attribute particular importance to the lack of Parliamentary scrutiny. Both the TO and the AQO were adopted without any Parliamentary oversight. Lord Hope found it unacceptable to confer unlimited discretion upon the executive in deciding how to implement UNSC resolutions, in the making of which the executive itself had participated. That would conflict with 'the basic rules that lie at the heart of our democracy'. 111

It will be remembered that the TO was found to be ultra vires because it exceeded what was necessary to implement Resolution 1373 (2001) to which it sought to give effect, whilst the AQO was found to be ultra vires because it made severe inroads into basic human rights which can be introduced only by primary legislation. This gives rise to the following question in relation to the TO: what would be the response of the Supreme Court if Resolution 1373 (2001) were expressly to cast the net wider and require the freezing of resources of those reasonably suspected of being associated with terrorism? Clearly, in such a case, the argument could be made that an Order in Council was necessary or expedient to implement the resolution. It would still be necessary, however, to examine whether the requirements of the principle of legality were satisfied. The question would be whether an Order in Council, adopted without Parliamentary scrutiny, freezing the assets of individuals, would fall within the scope of the delegation of powers permitted by section 1 of the 1946 Act. The Supreme Court accepted that some interference with human rights is possible by Orders in Council in order to give effect to UNSC resolutions. The question is how much interference the Court would be prepared to tolerate under delegated legislation. It may be argued that the AQO imposed a more severe limitation upon human rights than the TO, since it foreclosed any possibility of judicial review. Still, it is an open question whether in our hypothetical example an Order in Council would survive scrutiny. First, the effects of the freezing of assets on the personal life of the individuals concerned attracted much criticism by the Supreme Court and were described as 'traumatic'.112 Secondly, their permanent character exacerbated their restrictive effects. Under the TO, the freezing of funds was permanent, which made its intrusion into personal freedom and the rights of the individual particularly onerous. ${ }^{113}$

The Supreme Court held in essence that UNSC resolutions which interfere severely with basic human rights may not be introduced by delegated

111 Ibid, at [45].

112 Ibid, at [203], per Lord Brown.

113 See ibid, at [230], per Lord Mance. 
legislation which is not subject to Parliamentary scrutiny. ${ }^{114}$ It is clear that both the TO and the AQO could be introduced by primary legislation. This raises the following question: to what human rights limitations, if any, would primary legislation passed to comply with obligations arising from a UNSC resolution be subject? This issue was not examined by the Supreme Court.

A possible source of limitations might be provided by the Human Rights Act 1998. So long as Al Jedda remains good law, however, the Convention cannot trump obligations arising from the UN Charter. The Supreme Court might revisit its position in the event that in Al Jedda the Strasbourg Court takes the view that the UN Charter does not take precedence over the Convention. Even in such a case, it would be a matter for English law to decide whether to give priority to the Convention rather than the UN Charter and how conflicting obligations arising under the two systems might be compromised.

A second source of limitation may be found in EU law. Insofar as Member States act within the scope of EU law, they have an obligation to respect fundamental rights as guaranteed in the EU legal order. ${ }^{115}$ Under Article 6 of the TEU, as amended by the Treaty of Lisbon, there are essentially three sources of such rights: the EU Charter on Fundamental Rights; the European Convention; and the general principles of law articulated by the Court of Justice. This point is explored further below. ${ }^{116}$

A third limitation is found in jus cogens. English courts will not give effect to a UK statute which violates the peremptory rules of international law, although those rules are not defined with clarity and, in general, are so basic that this safeguard will provide protection only in the most extreme of cases.

A fourth limitation may be found in common law and stems from the principle of legality. As Lord Hope put it in Jabar Abmed, the more a measure affects the basic rights of the individual, 'the more exacting this scrutiny must become'. ${ }^{117}$ English courts will apply a presumption of constitutionality under which a statute will not be interpreted to deny a fundamental right unless the intention of the Parliament to this effect is crystal clear. Within the UK constitutional system, which is based upon the fundamental principle of Parliamentary supremacy, the determining criterion is the intention of Parliament. It would thus be a question of what kind of language the Parliament must use to persuade the courts that it authorises the executive

114 All their Lordships appeared to agree that a freezing of funds could be introduced by primary legislation. Whether it could also be introduced by delegated legislation which gave a greater role to Parliament, eg an Order in Council which was subject to the affirmative resolution procedure, remains an open question, although it is clear from the judgment that such a move would not be viewed favourably by the Supreme Court.

115 See Case C-260/89 ERT [1991] ECR I-2925.

116 See section IV.D. below.

117 Jabar Abmed, above n 92, at [45]. 
to breach human rights. The judgment in Jabar Abmed suggests that the Supreme Court is prepared to apply the principle of legality with an asphyxiating effect. Thus, where primary legislation seeks to implement a UNSC resolution that denies a fundamental right, the Court's inquiry is likely to focus on two aspects. First, it will look at the precise wording of the UNSC resolution to determine what effect it intends to have on human rights and the scope of the restriction it seeks to introduce. Given the UN's own commitment to human rights, the Court is likely to apply a strict construction to interferences with human rights and give the benefit of the doubt to an interpretation that provides for the least intrusion possible. Secondly, the Court will examine closely the domestic statute and will expect a high degree of precision. Any interference with human rights that is not absolutely necessary to comply with the UNSC resolution to which the statute intends to give effect, as that resolution is interpreted by the Court, will not be acceptable since Parliament will be presumed not to have intended to implement it.

The difference between English law and EU law is that the former, within the confines of the doctrine of Parliamentary supremacy, understands the principle of legality as a rule of construction. English courts will not understand the intention of Parliament to be to violate fundamental rights unless Parliament expressly states that this is so and uses the clearest and most specific language possible. ${ }^{118}$ By contrast, this will not do for the EU legislature. Even if the Council makes it clear that it wishes to act in breach of fundamental rights as they are protected in the EU, the Court of Justice will strike the measure down, however clear the language used by the Council. In that respect, EU law subscribes to a substantive version of the rule of law, whilst English law follows a (more) formal one. This is not to say, however, that the Court of Justice will necessarily follow a stricter level of scrutiny than that followed by English courts. Neither is it to say that the Court of Justice will necessarily exercise review of the merits rather than review of procedure. The difference of principle is fundamental, but the difference in results may be less so. As Lord Hoffmann put it in Simms, by the principle of legality English courts manage to apply

principles of constitutionality little different from those which exist in countries where the power of the legislature is expressly limited by a constitutional document. ${ }^{119}$

\footnotetext{
118 Note, however, that the principle of legality may not go as far as the duty of consistent interpretation imposed on English courts by s 3(1) of the Human Rights Act 1998. That section requires that, so far as it is possible to do so, legislation must be read and given effect to in a way which is compatible with the Convention rights. Lord Phillips stated that the principle of legality does not permit a court to disregard an unambiguous expression of Parliament intention, although in some cases s $3(1)$ has been understood as enabling courts to do precisely that: see ibid, at [117].

119 Ex parte Simms, above n 95, 131, cited with approval by Lord Phillips in Jabar Abmed, above $\mathrm{n}$ 92, at [111].
} 
The procedural character of the principle of legality under English law provides a discipline for the accurate and specific drafting of legislation which is absent in EU law. The narrow interpretation given by the Supreme Court to the powers granted to the executive by the 1946 Act contrasts sharply with the readiness of the Court of Justice in Kadi to accept that the EU had power to adopt economic sanctions against individuals on the somewhat feeble basis of Articles 215, 75, 352 TFEU (ex Articles 301, $60(1)$ and $308 \mathrm{EC}) .^{120}$

\section{Influence of EU law}

The influence of EU law in Jabar Abmed was only secondary and indirect. The appellants argued that the AQO ran counter to the right to a fair trial, the right to respect for family life and the right to property as protected by the ECHR. They conceded that the judgment of the House of Lords in Al Jedda established the primacy of the UN Charter over obligations flowing from the Convention, but invited the Supreme Court to reconsider $A l$ Jedda in the light of Kadi. The thrust of the argument was that, in the light of Kadi, the Strasbourg Court, before which Al Jedda was pending, could rule that Article 103 of the UN Charter did not trump the Convention. This argument was precarious. The Supreme Court rightly held that it could not speculate on how the European Court of Human Rights would decide in $\mathrm{Al}$ Jedda. ${ }^{121}$ It placed emphasis on that Court's judgment in Behrami and took a narrow view of Kadi.

Although the Supreme Court was correct to hold that it would be inappropriate to prejudge the result that the Strasbourg Court might reach in Al Jedda, the existing authorities make it far from clear that the European Court of Human Rights will accept unequivocally the primacy of UN obligations over the Convention. If that were not to be the case, English courts would be in the unenviable position of having to face a head-on clash between Convention rights and obligations emanating from the UN Charter. The solution offered by Lord Bingham in Al Jedda is that, in such a case, the Government must comply with the UN Charter whilst ensuring that the rights guaranteed by the Convention are not infringed to any greater extent than is inherent in the action necessary to comply with the relevant UN resolution. ${ }^{122}$ It seems that this would entail a balancing exercise performed by reference to a principle of proportionality applied not as a matter of the Convention, but as a matter of English law.

\footnotetext{
120 See section I. above.

121 See, eg, Al-Jedda, above n 103, para 74, per Lord Hope.

122 Ibid, para 39, per Lord Bingham.
} 
Although the relevance of Kadi in Jabar Abmed was only indirect, the reading of the Court of Justice's Kadi judgment by the Supreme Court was somewhat narrow. Lord Phillips stated that the judgment concerned 'the legitimacy of a Council Regulation judged against the rules of the autonomous and self-contained regime instituted under the EC Treaty' ${ }^{123}$ This was echoed by Lord Brown ${ }^{124}$ and supported by Lord Hope, who pointed out that the Court of Justice did not have to face the problem of primacy of UN obligations which Article 103 of the Charter raises for the Member States of the UN, since the institutions of the EU are not party to the Charter. ${ }^{125}$ In Kadi, however, the Court of Justice did not base its reasoning on the fact that neither the European Community nor the EU is a contracting party to the UN. Rather, it stated that review of the contested Council Regulation which implemented the sanctions list resolution 'would not entail any challenge to the primacy of that resolution in international law'. ${ }^{126}$ Thus, the Court of Justice based its reasoning on the fact that Article 103 of the UN Charter binds the Member States of the UN only in international law and does not interfere with their internal constitutional arrangements. For the Member States of the EU, part of those arrangements is the principle of primacy of EU law and the other obligations which flow from their EU membership. Thus, if one were to follow the Court of Justice's federalist rationale as it can be derived from the existing case law, obligations arising from EU law will take precedence over obligations arising from the UN Charter since, for the purposes of Article 103 of the UN Charter, EU law has to be seen as an integral part of national law. The EU, in other words, establishes an internal constitutional space for all EU Member States which forms part of the domestic law of each Member State, and which is not penetrated by the sharp end of Article 103 of the Charter.

Thus, whilst the implication from Jabar Abmed is that the judgment in Kadi does not have an impact upon national measures adopted to give effect to UNSC resolutions, this is by no means clear from the reasoning of the Court of Justice in Kadi itself. In Jabar Abmed, the Court was not faced with the argument that the AQO might fall within the scope of EU law and therefore that human rights as protected by the EU legal order must be respected. It is worth examining this scenario in more detail.

Suppose that the name of an EU national, who is resident in the UK and who carries on economic activities in other EU States and regularly moves funds from the UK to other States, is included in the UN sanctions list. The freezing of his assets is clearly a restriction upon his right to free movement. The precise freedom which may be engaged is less relevant and it would

123 Jabar Abmed, above n 92, at [104], per Lord Phillips.

124 Ibid, at [203].

125 Ibid, at [71].

126 Kadi, above n 1, para 288. 
depend on the facts. It could be the free movement of capital, his freedom of establishment, or his freedom to provide services. The justification for this restriction is to be found in the need to safeguard public security, to combat terrorism and ensure international peace and security, and to comply with the UNSC resolutions which dictate the inclusion of his name in the sanctions list. Under the established case law of the Court of Justice, however, a restriction on free movement can be justified only if it respects fundamental rights as protected in EU law. ${ }^{127}$ Does that mean that a national measure implementing the sanctions list must observe EU fundamental rights? The Government could counter-argue that, under Article 351(1) TFEU (ex Article $307(1)$ EC), obligations arising from pre-existing international agreements concluded by the Member States are not to be affected by the provisions of the EU Treaties. On this basis, EU human rights would not be applicable since the individual EU States' membership of the UN precedes their membership of the European Community and the EU.

This argument, however, encounters an important objection. Article 351(1) TFEU does not give the complete picture. Article 351(2) TFEU (ex Article $307(2)$ EC) states that, to the extent that pre-existing international agreements are not compatible with the EU Treaties, Member States must take all appropriate steps to eliminate the incompatibilities established. This is a 'best efforts' clause which has received a strict interpretation favourable to the EU. It follows that, insofar as a UNSC resolution breaches fundamental rights as guaranteed by EU law, Member States, including national courts, are under an obligation to eliminate that breach. The precise obligations which flow from this are not clear and will need to be decided on a case-by-case basis. It is important to note, however, that in Kadi the Court of Justice expressly held that Article 351 TFEU (ex Article 307 EC) cannot

be understood to authorise any derogation from the principles of liberty, democracy and respect for human rights and fundamental freedoms enshrined in Article 6(1) EU ...128

and

may in no circumstances permit any challenge to the principles that form part of the very foundations of the Community legal order, one of which is the protection of fundamental rights... ${ }^{129}$

The peremptory language used by the Court of Justice suggests that Article 351 TFEU does not preclude judicial review on grounds of compatibility

127 Case C-260/89 ERT [1991] ECR I-2925; Case C-368/95 Vereinigte Familiapress Zeitungsverlags- und Vertreibs GmbH v Bauer Verlag [1997] ECR I-3689; Case C-71/02 Herbert Karner Industrie-Auktionen GmbH v Troostwijk GmbH [2004] ECR I-3025.

128 Kadi, above n 1, para 303.

129 Ibid, para 304. 
with EU rights of a national measure which has been adopted to give effect to a UNSC resolution but which falls within the scope of EU law. A number of concomitant issues arise in this context. Could it be said, for example, that the standard of scrutiny of such a national measure would be lower than that applicable to determine the compatibility of a measure adopted by the EU institutions? It is not clear why the answer to this question should be in the affirmative.

\section{CONCLUSION}

There is a striking degree of convergence among courts in the EU, the UK and beyond to the effect that responses to emergencies which make for serious intrusions on fundamental rights should be channelled through constitutional procedures and institutional practices which are most respectful of democracy, accountability and the rights of the individual. The EU legal system is committed to a substantive version of the rule of law, while English law, bred in the doctrine of Parliamentary supremacy, subscribes to a formal version. Despite the fact that the two systems commence from different points of principle, the difference in judicial outcomes is less clear. English courts have proved skilful in applying the principle of legality with an asphyxiating effect for the executive.

Neither Kadi nor the judgment in Jabar Abmed addresses some fundamental problems which may result from the interaction between national law, UN obligations and EU law. In particular, it is not clear whether, in the event of a conflict between obligations flowing from EU law and obligations flowing from the UN Charter, national courts will give precedence to the former or to the latter. Although the Court of Justice did not have to confront the issue directly in Kadi, as a matter of EU law, the answer appears clear: national courts should give effect to EU law obligations. This solution is dictated by the principle of primacy and the fact that the Court of Justice treats EU and national law as two tiers of the same legal system which can be viewed as part of domestic law for the purposes of Article 103 of the UN Charter. Any other solution would contradict the solutions reached by the Court of Justice. If, under the principle of primacy of EU law, the latter takes precedence over the national constitutions, why should it not take precedence over obligations emanating from membership of the UN? After all, those obligations can be given effect only in accordance with the national constitutions and, from the point of view of EU law, are part of them and thus subordinate to EU law. Whether such strict EU law orthodoxy would be accepted by the national courts remains to be seen. Too strict an orthodoxy carries with it a higher risk of rebellion. The bottom line is that we are faced again with the problem of KompetenzKompetenz, to which there is no conclusive answer. Is it national courts or 
the Court of Justice which have ultimate authority to determine the scope of application of EU law? In English law, the parameters are firmly set by the doctrine of Parliamentary supremacy. It will thus be a question of ascertaining what the judiciary perceives to be the true wishes of the UK Parliament as to the priority between EU and UN obligations in any given context. 